Number 7

\title{
MAKROFAG DAN ATEROSKLEROSIS
}

\author{
IGA Dewi Sarihati ${ }^{1}$ \\ dewisarihatiiga@yahoo.co.id
}

\begin{abstract}
Inflammation in atherogenesis occurs because of the interaction between leukocytes, platelets and cells of the blood vessel wall. Stimulation of atherosclerosis risk factors as well as hypercholesterolemia will increase the production of monocytes in the bone marrow. Monocytes enter the arteria and attach to the endothelial cells and turn into macrophages after arriving at the subendotel space. High LDL in hypercholesterolemia will result in the occurrence of LDL oxidation to be phagocytosed by macrophages and thus transform into foam cells that are the early stages of atherogenesis. Increased activity of M1 macrophages will promote atherogenesis while increased M2 macrophage activity will result in improvement of lesions in the arteries. To reduce the occurrence of atherosclerosis is preventing the occurrence of inflammation in the walls of blood vessels due to hypercholesterolemia.
\end{abstract}

Keywords: macrophages; atherosclerosis, inflammation

\section{Pendahuluan}

Aterosklerosis terjadi pada arteri yang lebih besar yang ditandai dengan penebalan atau pengerasan dindingnya. Lesi unit atau ateroma (bercak aterosklerosis) terdiri dari masa bahan lemak dengan jaringan ikat fibrous ${ }^{1}$. Aterosklerosis sering dihubungkan dengan gangguan metabolisme lemak. Kemudian berkembang pemahaman tentang adanya peranan inflamasi dalam patogenesis aterosklerosis sehingga sekarang dianggap sebagai penyakit yang dimediasi peradangan karena adanya interaksi yang kompleks antara leukosit, trombosit dan sel-sel dari dinding pembuluh darah ${ }^{2}$.

Sel kekebalan utama yang berperan pada lesi aterosklerosis adalah makrofag,

\footnotetext{
1. Jurusan Analis Kesehatan Poltekkes Denpasar Korespondensi : IGA Dewi Sarihati ${ }^{1}$, Jurusan Analis Kesehatan, Poltekes Denpasar, Jalan Sanitasi No. 1 Sidakarya, Denpasar-Bali 80224, Indonesia.

Telp. +62-361-710 527, Fax. +62-361-710 448

Email : meditoryjournal@gmail.com
} 
yang asal mulanya merupakan sel progenitor myeloid di sumsum tulang. Sel progenitor myeloid berkembang menjadi monosit dalam sirkulasi, sedangkan penelitian pada tikus menunjukkan bahwa limpa juga berperan sebagai reservoir untuk monosit yang masuk ke dalam lesi aterosklerosis ${ }^{3}$. Produksi monosit di sumsum tulang dirangsang oleh beberapa faktor risiko kardiovaskular, termasuk hiperkolesterolemia, yang menyebabkan monositosis yang merupakan faktor risiko independen untuk penyakit aterosklerotik ${ }^{4}$. Monosit kemudian masuk ke tempat-tempat stres hemodinamik arterial dan menempel pada sel endotel yang melapisi lumen $\operatorname{arteri}^{5}$. Begitu monosit memasuki ruang subendotel, akan berubah jadi makrofag lesi ${ }^{6}$.

Makrofag ada dua kelompok yaitu M1 dan M2. M1 makrofag, adalah yang diaktifkan secara klasik dan dikenal sebagai makrofag "pembunuh" ("killer" macrophages) diaktifkan oleh Lipopolysaccharides (LPS) dan Interferon gamma (IFN $\gamma$ ). Kelompok M1 mengeluarkan sitokin proinflamasi dengan kadar yang tinggi dan sitokin antiinflamasi kadar rendah. Sebaliknya, M2 yang dikenal dengan makrofag "perbaikan" (juga disebut sebagai makrofag alternatif) secara umum mengacu pada makrofag yang berfungsi dalam proses konstruktif seperti penyembuhan luka dan perbaikan jaringan, dan yang mematikan aktivasi sistem kekebalan yang merusak dengan memproduksi sitokin anti-inflamasi seperti interleukin 10 (IL-10) ${ }^{7}$.

\section{Pembahasan}

Inflamasi ringan pada arteri mengawali aterosklerosis yang kemudian dapat berkembang menjadi lebih berat ${ }^{8}$. Salah satu teori terjadinya aterosklerosis adalah hipotesis respon terhadap cedera, dengan beberapa bentuk cedera tunika intima yang mengawali inflamasi kronis dinding arteri dan menyebabkan timbulnya ateroma. Tahap awal dari aterogenesis adalah cedera yang kemudian menyebabkan disfungsi endotel dengan meningkatkan permeabilitas terhadap monosit dan lipid darah.

Cedera pada endotel yang mengakibatkan terganggunya fungsi 
endotel sebagai akibat dari hiperkolesterolemia yang meningkatkan produksi radikal bebas oksigen. Radikal ini menonaktikan oksida nitrat yaitu faktor endothelial relaxing yang utama. Sehingga aterosklerosis ada keterkaitan dengan defisiensi pelepasan oksida nitrat (NO) dan gangguan vasodilatasi. Dalam hal ini low density lipoprotein (LDL) teroksidasi berperan menghambat produksi $\mathrm{NO}^{1}$.

Oksidasi LDL berperan dan mempercepat terjadinya plak ateromatosa dengan jalan merangsang sel endotel, sel otot polos dan makrofag menghasilkan monocyte chemoattractant protein-1 (MCP-1) yang berperan penting mengatur infiltrasi monosit / makrofag ke dinding arteri termasuk migrasi monosit ke ruang subendotelial ${ }^{9}$. Aktivasi endotel akan mengekspresikan molekul adhesi yang mengakibatkan adhesi leukosit mononuklear, seperti monosit dan T-sel pada endotel serta migrasi ke intima. Pada tahap ini, juga ditemui adanya sel dendritik, neutrofil dan sel-B bersama sel otot polos ${ }^{10,11}$.
Monosit ditransformasikan ke makrofag dan memfagositosis oksidasi LDL, kemudian menjadi sel busa (foam cell), yang beragregasi dalam lapisan intima, dan terlihat secara makroskopis sebagai bercak lemak (fatty streak) $)^{1,11}$. Makrofag diaktifkan oleh Polymorphonuclear (PMN) diikuti sekresi tumor necrosis factor (TNF)- $\alpha$, interleukin (IL)-8, dan interferon- $\gamma$ (IFN$\gamma)$. Selain itu, pelepasan myeloperoxidase akibat dari aktivasi PMN dapat merangsang pembentukan spesies oksigen reaktif $(R O S)$, serta sekresi sitokin pro-inflamasi lainnya, termasuk TNF- $\alpha$, IL-1, IL-6, IL-8 dan granulocyte macrophage colony stimulating factor (GM-CSF) dari makrofag. ROS yang terbentuk ini akan mengubah LDL menjadi oksidasi LDL dan mengakibatkan pembentukan sel busa kembali $^{12}$. Setelah migrasi dari sirkulasi ke dalam intima dinding arteri, monosit dikonversi ke makrofag dan sel dendritik. Sel-sel ini kemudian berubah menjadi sel busa dengan mengambil lipoprotein yang telah dimodifikasi ${ }^{12}$. Lipoprotein mengikat proteoglikan yang disekresikan oleh monosit dalam intima, sehingga 
menyebabkan peningkatan akumulasi LDL dimodifikasi, dan mengakibatkan inflamasi ${ }^{13}$. Kerusakan jaringan dan perbaikan terkait erat dengan monosit, dan perbedaan terjadinya proses ini penting artinya dalam pembentukan dan stabilitas plak. Monosit terdiri dari subset yang berbeda dengan marker pada permukaan sel dan fitur fungsionalnya juga berbeda, dan keragaman komponen ini berhubungan dengan proses angiogenik di aterosklerosis.

Pembentukan lesi aterosklerotik sangat tergantung pada transformasi monosit menjadi makrofag; misalnya, defisiensi macrophage colony-stimulating factor pada mencit (M-CSF-KO mice) menunjukkan resistensi terhadap perkembangan aterosklerosis ${ }^{15}$. Setiap fase perjalanan penyakit diikuti jumlah monosit-makrofag yang bertambah banyak dan sel-sel ini berperan penting dalam akumulasi lipid dan perkembangan aterosklerosis $^{11,13}$. Peran pentingnya dalam aterogenesis telah terbukti dengan berkurangan pembentukan lesi pada mencit dengan monocyte-deficient apolipoprotein E knockout dan mencit LDL receptor knockout ${ }^{16,17}$. Polarisasi makrofag untuk menjadi fenotipe tertentu berhubungan dengan adanya lipid, faktor pertumbuhan (growth factor), dan sitokin; makrofag M1 dapat mengakibatkan kerentanan plak, sedangkan makrofag M2 yang diaktifkan oleh metode alternatif dapat meningkatkan stabilitas plak $^{18}$. Fenotip M1 / M2 makrofag bisa ditukar tergantung pada kondisi lingkungan mikro $^{19}$. Pada fase sangat awal aterogenesis ditemukan banyak makrofag dan sel dendritik yang memiliki membran dengan tertempel lipid dalam sitoplasma.

Sitokin inflamasi dan kemokin yang mendukung terjadinya peradangan dan berkontribusi pada regulasi monosit / infiltrasi sel T dihasilkan oleh makrofag / sel busa ${ }^{20}$. Dengan adanya makrofag dalam plak aterosklerosis, memungkinkan untuk menghasilkan berbagai sitokin proinflamasi seperti IL-1, IL-6, IL-12, IL15, IL-18, TNF, dan macrophage migration inhibitory factor (MIF), serta sebagai sitokin anti-inflamasi seperti IL10 dan transforming growth factor beta $(T G F-\beta)^{21}$. Selain itu, IFN $\gamma$ dapat memicu makrofag untuk memproduksi spesies oksigen reaktif atau reactive oxygen species (ROS) dan neopterin. 
Peningkatan neopterin terjadi pada sindrom koroner akut dan berguna untuk penilaian peradangan yang terkait dengan aterosklerosis ${ }^{11}$.

\section{Simpulan}

Makrofag memiliki peran yang penting dalam aterosklerosis yang didasari proses inflamasi. Sebagai bagian dari system pertahanan tubuh, makrofag dapat memfagositosis LDL teroksidasi dan menghasilkan sitokin proinflamasi dan antiinflamasi. Makrofag M1 mendorong terjadinya aterosklerosis sedangkan makrofag M2 memperbaiki lesi sehingga apabila LDL teroksidasi berkurang maka makrofag M1 berkurang dan kerja makrofag M2 tidak terhambat.

\section{Pustaka}

1. McPhee, S.J dan Ganong,W.F. Patofisiologi Penyakit: Pengantar Menuju Kedokteran Klinis (Brahm U. Pendit). Jakarta: EGC. 2011.
2. Omoigui, S. The Interleukin-6 Inflammation Pathway from Cholesterol to Aging-Role of Status, Bisphosphorates and plant polyphenols in Aging and Agerelated Diseases. (online), (cited 2017 Jan.18). Available from: http://www.immunityageing.com. 2007.

3. Robbins CS, Chudnovskiy A, Rauch PJ, et al. Extramedullary hematopoiesis generates Ly6C(high) monocytes that infiltrate atherosclerotic lesions. Circulation. ;125:364-374. 2012.

4. Swirski FK, Libby P, Aikawa E, Alcaide P, Luscinskas FW, Weissleder R, Pittet MJ. Ly-6Chi monocytes dominate hypercholesterolemia-associated monocytosis and give rise to macrophages in atheromata. J Clin Invest.;117:195-205. 2007.

5. Gerhardt T, Ley K. Monocyte trafficking across the vessel wall. Cardiovasc Res. 2015.

6. Randolph GJ. Mechanisms that regulate macrophage burden in 
atherosclerosis. Circ Res. 2014;114:1757-1771.2014.

7. David M. Mosser \& Justin P. Edwards. "Exploring the full spectrum of macrophage activation". Nature Reviews Immunology. 8 (12): 958-969. 2008.

8. Dessì, M., Noce, A., Bertucci, P., Simone Manca di Villahermosa, Rossella Zenobi, R., Veronica Castagnola,V. et al.. Review Article Atherosclerosis, Dyslipidemia, and Inflammation: The Significant Role of Polyunsaturated Fatty Acids. ISRN Inflammation, (online)(cited $2017 \quad$ Jan 14) Available from: http://dx.doi.org/10.1155/2013/19 1823. 2013.

9. Nakashima,Y., Thomas N. Wight, and Sueishi, K. Early atherosclerosis in humans: role of diffuse intimal thickening and extracellular matrix proteoglycans. Cardiovascular Research 79, 14-23. 2008.
10. Frostegård, J. Immunity, Atherosclerosis and Cardiovascular Disease. BMC Med.; 11:117. 2013.

11. Ilhan, F and Kalkanli, S.T. Atherosclerosis and The Role of Immune Cells. World J Clin Cases; 3(4): 345-352. 2015.

12. Tavakoli, S, and Asmis, R. Reactive Oxygen Species and Thiol Redox Signaling in The Macrophage Biology of Atherosclerosis. Antioxid Redox Signal. ;17:1785-1795. 2012.

13. Profumo, E., Buttari, B., Saso, L., Capoano, R., Salvati, B., Riganò, R. 2012. T Lymphocyte Autoreactivity in Inflammatory Mechanisms Regulating Atherosclerosis. Scientific World Journal; 2012:157-534.2012.

14. Tabas I. 2010. Macrophage Death and Defective Inflammation Resolution in Atherosclerosis. Nat Rev Immunol.; 10:36-46. 2010. 15. Smith, J.D., Trogan, E., Ginsberg, M., Grigaux, C., Tian, J and Miyata, M. Decreased Atherosclerosis in Mice Deficient 
in Both Macrophage ColonyStimulating Factor (Op) And Apolipoprotein E. Proc Natl Acad Sci USA; 92:8264-8268.1995. 16. de Villiers, W. J., Smith, J.D., Miyata, M., Dansky, H.M., Darley, E., Gordon, S. Macrophage Phenotype in Mice Deficient in Both MacrophageColony-Stimulating Factor (Op) And Apolipoprotein E. Arterioscler Thromb Vasc Biol.; 18:631-640. 1998.

17. Rajavashisth, T., Qiao, J.H., Tripathi, S., Tripathi, J., Mishra, N., Hua, M., et al. Heterozygous Osteopetrotic (Op) Mutation Reduces Atherosclerosis in LDL Receptor- Deficient Mice. J Clin Invest.; 101:2702-2710. 1998.

18. Seneviratne, A.N., Sivagurunathan, B., Monaco, C. Toll-Like Receptors and Macrophage Activation in Atherosclerosis. Clin Chim Acta; 413:3-14. 2012.

19. Lee, S., Huen, S., Nishio, H., Nishio, S., Lee, H.K., Choi, B.S., et al. Distinct Macrophage
Phenotypes Contribute to Kidney Injury and Repair. J Am Soc Nephrol; 22:317-326. 2011. 20. Wolfs, I.M., Donners, M.M, de Winther, M.P. Differentiation Factors and Cytokines in The Atherosclerotic Plaque MicroEnvironment as A Trigger for Macrophage Polarisation. Thromb Haemost.; 106:763-771. 2011. 21. de Jager, S.C., Bermúdez, B., Bot, I., Koenen, R.R., Bot, M., Kavelaars, A, et al. Growth Differentiation Factor 15 Deficiency Protects Against Atherosclerosis By Attenuating CCR2-Mediated Macrophage Chemotaxis. J Exp Med.; 208:217-225. 2011. 